\title{
Mindre bidrag
}

\author{
En Lålesamling
}

A remark on the proverb collection of Peter Låle in view of the manuscript Uppsala universitetsbibliotek C 22.

Det middelalderlige latin-svenske glossar fra 1400-tallets anden halvdel, der findes i håndskriftet Uppsala universitetsbibliotek C 20, har stor betydning for studiet af Peder Låles ordsprogssamling, fordi der tre steder i glossaret henvises til »Petrus Laalæ«. Disse henvisninger er de første oplysninger om samlingens kompilator, vi kender. Iver Kjær omtaler af denne grund C 20 som »det værdifuldeste aktstykke til Peder Låle-samlingens datering « (DgO I:2 s. 728).

Også det noget ældre Uppsalahåndskrift C 22 rummer et latin-svensk glossar, men dette samlingshåndskrift rummer desuden en lang række andre tekster på latin og svensk. Her er det navnlig interessant at fremdrage hvad håndskriftets første beskriver, Johan Henrik Schröder, har fundet. Nemlig at der i en latinsk ordsprogssamling optræder to nordiske paralleller (her citeret fra hs., bl. 138v): ${ }^{1}$

Interdum semi vox intellecta sit hemi.

Man ma forsta halff kuædhit ordh

Lente plaga dolet quce fore crebra solet.

Man ma sua vænias vidh ont at onth ær goth

De to par svarer med visse variationer til PL A 528 og A 555. I erkendelse heraf har jeg foretaget en kollationering af ordsprogssamlingens alfabetiske del (bl. 135v-146r), der har vist sig at stå i forbindelse med Låleoverleveringen. Dette er nyt; Schröder nævner ikke Låle, og ingen har heller siden inddraget C 22 i overvejelser om denne samlings historie og struktur.

1 Schröder har beskrevet håndskriftet $\mathrm{i}$ en kort latinsk afhandlning: Glossarii Latino-svethici specimen vetustum. E codice mscr. bibliothecce Reg. Acad. Upsal. Particulam primam, Uppsala 1845. Det er siden blevet katalogiseret af Margrete Andersson-Schmitt og Monica Hedlund i Mittelalterliche Handschriften der Universitätsbibliothek Uppsala: Katalog über die C-Sammlung. Bd. 1. Stockholm 1988, s. 227-232, hvor imidlertid de to nordiske ordsprog ikke omtales. 
Da samtlige andre tekstvidner til Låleoverleveringen er tryk og håndskrifter der kun indeholder denne tekst, er det desuden væsentligt at undersøge om ordsprogssamlingen har forbindelse til C 22's øvrige tekster. Dette kan vise sig særligt interessant fordi C 22 stammer fra Vadstenas klosterbibliotek.

Jeg regner med i et kommende arbejde at undersøge C 22 og hvad det kan sige om Lålesamlingens ældste overlevering.

Simon Skovgaard Boeck

\section{Leonardo da Vinci}

\section{Et utrykt essay af Sophus Claussen}

This paper presents a hitherto unpublished essay by the Danish symbolist poet Sophus Claussen (1865-1931). The essay entitled 'Leonardo da Vinci' was intended for the collection Løvetandsfnug ('dandelion fluff'), 1918, but was for unknown reasons omitted in the final edition. In the essay, Claussen recalls when, at the Uffizi Gallery in Florence in 1902-03, he saw a painting (perhaps by Leonardo da Vinci) depicting the Annunciation to the Blessed Virgin Mary. At the time, the Virgin Mary of the painting reminded Claussen of a young Danish girl with whom he had been hopelessly in love some ten years prior. The remembrance of this past experience, at the time of writing the essay in early or mid 1918, causes him to contemplate not only the artistic method of Leonardo, but also, more generally, the relationship between chastity and lust, nature and imitation, and art and science. 'Leonardo da Vinci' has never been described in the secondary sources on Claussen's work. It is, however, arguably both interesting and exemplary for its dual role as both a biographical and poetological lead in his essays and in his oeuvre as a whole.

Sophus Claussen (1865-1931) var en produktiv forfatter gennem en stor del af sit liv. Foruden digtbøger, romaner, skuespil og en enkelt novellesamling udgav han i aviser og tidsskrifter flere end 1500 enkeltstående tekster heriblandt artikler, anmeldelser og erindringsstykker. Nogle af de bedste af disse indgik siden i de to essaysamlinger: Løvetandsfnug (1918) og Foraarstaler (1927). Samlingerne består begge af fortrinsvis tidligere trykte tekster, men indeholder også nyskrevet materiale. Her skal præsenteres et nyskrevet essay, der oprindeligt var tiltænkt Løvetandsfnug, men som af uvisse årsager blev udeladt i den endelige redaktion. Essayet bærer titlen »Leonardo da Vinci« og er bevaret $\mathrm{i}$ Claussens arkiv på Det Kgl. Bibliotek i tre manuskriptvarianter: en renskrift, en kladde og et udkast. Det er antagelig skrevet i foråret el- 